\title{
MECHANICAL PROPERTIES OF POLISH-GROWN PINUS SYLVESTRIS L. STRUCTURAL SAWN TIMBER FROM THE BUTT, MIDDLE AND TOP LOGS
}

\author{
SŁawomir Krzosek, Marek Grześkiewicz, \\ Izabela Burawska-Kupniewska, Piotr Mańkowski \\ Warsaw University of Life Sciences - SGGW \\ Poland \\ Marek Wieruszewski \\ Poznań University of Life Sciences \\ PolAnd \\ (Received December 20ig)
}

\begin{abstract}
The research consisted in testing Polish sawn timber dedicated for construction applications made of pines (Pinus sylvestris L.) that grew in the Silesian Forestry Region, taking into account three parts of the log: butt, middle and top. The boards had the same cross section, a nominal thickness of $40 \mathrm{~mm}$ and width of $138 \mathrm{~mm}$, typical for Polish structural timber. The mean nominal length of the boards under research amounted to $3500 \mathrm{~mm}$. Each set was composed of 70 boards. Before the tests, boards were dried in an industrial drier until reaching the moisture content of $12 \%$, and they were planed on 4 sides. First of all, the sawn timber was graded into strength classes, and their dynamic modulus of elasticity (MOE_dyn) was tested with a non-destructive method, with the use of a portable MTG device. The next step consisted in a bending test with four points of support, according to the EN 408 standard, and with the use of the TiraTest 2300 machine, in order to determine the global modulus of elasticity (MOE_EN-408) and the static bending strength, also referred to as modulus of rupture (MOR). Finally, the average growth ring width was determined for each board (PN-D-94021), as well as wood density according to EN-408. The hereby paper presents the test results for all the tested sawn timber boards, taking into account the part of log that each board came from: butt, middle or top. The hereby paper presents the influence of density on the mechanical properties of wood, taking into account the location on the round timber. The analysis does not include the influence of the width of annual growth rings and the proportion of latewood on the wood properties under research.
\end{abstract}

KEYWORDS: MOE, MOR, pine sawn timber, butt, middle and top. 


\section{INTRODUCTION}

In accordance with the requirements binding in the European Union, sawn timber dedicated to construction application has to be strength graded. There are two methods of strength grading of coniferous timber for construction applications: visual and machine-assisted strength grading. Strength grading based on visual inspection consists in examining every piece of timber carefully and classifying it within the appropriate strength class on the basis of visible defects of wood structure, shape and processing. As a result of strength grading based on visual inspection, the timber is classified into different grades. Most EU member state have their own, national standards for the visual strength grading of timber. The only common requirement that has to be fulfilled by the national standards of visual strength grading is that they have to comply with EN 14081-1.

Strength grading machines measure specific wood properties that can be verified in a non-destructive way and that are directly correlated with wood's bending strength. The higher the correlation between the property tested by the machine and the bending strength, the more reliable will be the results of strength grading performed by that machine. In Europe, many different kinds of devices were developed and introduced at an industrial scale, and have been described by many researchers (Glos 1982, Denzler et al. 2005, Krzosek 2005 and 2009, Karlsson 2009, Krzosek and Bacher 2011). Strength grading machines can be based on measuring the density and modulus of elasticity of the tested timber. The modulus of elasticity can be measured in bending (static modulus of elasticity) or with the use of ultrasounds or frequency of own vibrations (dynamic modulus of elasticity). The density of the tested timber can be determined with a stereometric method or with the use of X-rays (Bucur 2003).

Krzosek and Grześkiewicz (2008) compared the results of visual and machine strength grading done for the same batch of timber with the use of MTG. As a result of the conducted tests, concluded that the use of the device causes a higher efficiency in better strength grades, comparing to the results of the visual strength grading method, with less pieces being rejected. Similar results have been obtained by Krzosek (2009), who tested a batch of pine timber (766 pieces). Comparative research was also conducted for the modulus of elasticity of pine timber from Lithuania $(3006 \times 90 \times 35 \mathrm{~mm})$. In this study, the result of static bending strength in four-point flexural test achieved with the use of a Metriguard device was slightly higher (modulus of elasticity in static bending $11323 \mathrm{MPa}$, dynamic modulus of elasticity $10351 \mathrm{MPa}$ ). Higher values of density of the wood under research went together with bigger differences between the MOE values obtained with different methods. The relation between MOR and MOE measured with different methods (MTG, using Metriguard machine by passing specimens flat-wise through it, flatwise bending test equipment Long Span) was similar (Mišeikyte et al. 2008, Baltrušaitis and Mišeikytė 2011).

A comparison of non-destructive and destructive tests of spruce (and oak) wood, with the use of the Fakopp ultrasound sensor, longitudinal vibration method and static bending test were presented by Oberhofnerová et al. (2016). The correlation between the modulus of elasticity determined with dynamic and static method in line with ČSN 490116 amounted to $\mathrm{R}=0.71$. The MOE determined with the dynamic method was by over $60 \%$ higher than the MOE determined with the static method.

Tests of spruce wood $(35 \times 70 \times 2700 \mathrm{~mm}$ ) were carried out by Posta (Posta et al. 2016). In this study, the values of dynamic modulus of elasticity determined with the use of Timber Grader MTG, Sylvatest and Fakopp, were compared to the values obtained with bending methods. The researchers obtained high coefficients of determination for the modulus of elasticity determined with Sylvatest and the modulus of elasticity obtained with the static method in bending 
$\mathrm{R}^{2}=0.94$. Similarly, the coefficient of determination obtained for the modulus of elasticity with the Fakopp device amounted to $\mathrm{R}^{2}=0.95$, and for $\mathrm{MTG} \mathrm{R}^{2}=0.97$ ).

A comparison of properties of Douglas fir wood and spruce from forest lands and post-agricultural lands was presented by Zeidler for wood from the Czech Republic (Zeidler and Borůvka 2017). The density was similar (spruce $460 \mathrm{~kg} \cdot \mathrm{m}^{-3}$, Douglas fir $570 \mathrm{~kg} \cdot \mathrm{m}^{-3}$ ), spruce wood from permanent forest land had a slightly higher MOE than wood from forested agricultural land (7541 MPa / $7744 \mathrm{MPa}$ ), and the difference was higher for Douglas fir (9783 MPa / $8940 \mathrm{MPa}$ ). A comparative study of pine wood from forest and post-agricultural lands was conducted by Jelonek et al. (2009). For wood from a fresh coniferous stand growing in a forest area, the density of wood amounted to $452 \mathrm{~kg} \cdot \mathrm{m}^{-3}$, and in post-agricultural lands it amounted to $470 \mathrm{~kg} \cdot \mathrm{m}^{-3}$.

Another important matter is knowledge related to the usability of different kinds of logs (butt, middle and top) for the production of structural timber. Studies aimed at verifying the influence of log type on the mechanical properties of structural timber obtained from them were carried out in various countries. Glos et al. 1999, tested spruce wood from two different habitats in Bavaria. The timber was strength graded with a visual method and with a machine method, taking into account the place of origin of timber from different logs. The highest efficiency of the strength grade S13 (DIN 4074-1): 79\%, was achieved for butt logs; while in case of middle logs the efficiency reached $40 \%$. As a result of machine strength grading of the same timber batch, the efficiency of the MS13 class (DIN 4074-4) amounted to $81 \%$ for butt logs and $71 \%$ for middle logs.

In Austria, within the framework of the XXL-Wood project (Teischinger and Patzelt 2006), an extensive study of spruce was conducted, taking into account the origin of wood, the conditions of growth, the quality class and the type of logs (butt, middle, top) from which the tested timber was obtained. The timber obtained from the logs was strength graded with the machine method, the dynamic modulus of elasticity was determined by measuring the frequency of own vibrations, and afterwards, the modulus of elasticity in stretching, the average width of growth rings, density and fibre twist were tested. The test results permitted to conclude that the mechanical properties of wood remain stable up to the height of 12-15 m.

Stőd et al. (2016) conducted research related to the determination of MOE and MOR for pine wood from Finnish forests. The tested wood from different regions, with quite diverse density between $474 \mathrm{~kg} \cdot \mathrm{m}^{-3}$ and $546 \mathrm{~kg} \cdot \mathrm{m}^{-3}$, and mechanical properties: MOR (42.7 MPa, 65.8 MPa), MOE (11.4 GPa, 14.9 GPa). Moreover, they tested the properties of wood from the first and second thinning, as well as the final logging, and also the influence of the log part (butt, middle or top) on the properties of timber acquired from them. The results of that research revealed most of the timber that was classified within the highest resistance grades (C30 and C35) was acquired during the 2nd thinning. For structural timber obtained from the final logging, it turned out that there is no statistically significant difference between the main density of timber obtained from middle and top logs. The MOR of timber obtained from butt, middle and top logs amounted to, respectively: 56.1 MPa, 39.7 MPa and 36.4 MPa; and the MOE values: $13.5 \mathrm{GPa}, 11.7 \mathrm{GPa}$ and $10.2 \mathrm{GPa}$.

Ranta-Maunus et al. (2009, 2011) prepared extensive reports from research conducted on timber from Europe and Russia. The timber was tested using non-destructive methods, with the use of various devices that are used in Europe (GoldenEye 706, Escan, MTG, Combiscan, Triomatic) and also with a destructive method, in line with EN 408. This research did not take into account the type of log that timber was obtained from. According to the report, non-destructive methods used to determine the modulus of elasticity tend to give higher values than the modulus of elasticity determined with the destructive method. 


\section{MATERIAL AND METHODS}

\section{Material}

The material investigated within the research described in the hereby paper originated from the Silesian Region. The timber was obtained from a mixed, young forest located in the Regional National Forest Directorate of Katowice (Nadleśnictwo Olesno, Leśnictwo Sternalice department 14d, geographical coordinates: 50.898629, 18.423915). The boards used in the research came from three types of logs: butt, middle and top.

Tree trunks were cut into 3 logs, each $3.5 \mathrm{~m}$ long: first, $1 \mathrm{~m}$ adjacent to the ground was cut off to remove the root deformations. Later, the butt log was obtained. A section for small samples, $0.5 \mathrm{~m}$ long, was cut between the butt $\log$ and the middle log. Later, the middle log was cut. The top log was obtained as follows: the diameter of $\mathrm{d}=14 \mathrm{~cm}$ was found in the top part of the trunk (diameter on the thinner end, according to PN 93-D-02002) and $3.5 \mathrm{~m}$ were measured from that point (Fig.1).

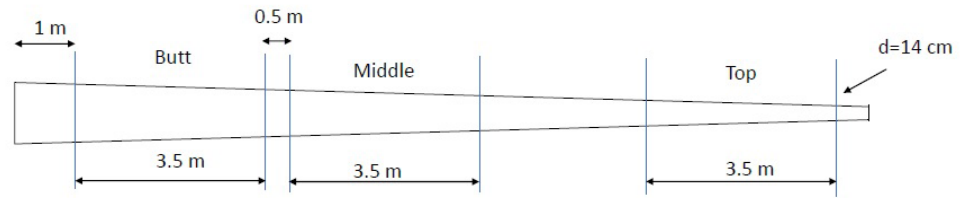

Fig. 1: Diagram presenting divisions of the trunk into logs.

Subsequently, 70 board pieces were sawn from each kind of logs (butt, middle and top). The boards were dried in an industrial drier until reaching the moisture content of ca. $12 \%$, and then they were planed on four sides. The nominal cross sections of the boards had the dimensions $40 \times 138 \mathrm{~mm}$, and the length of $3500 \mathrm{~mm}$.

\section{Methods}

The moisture content of wood, before testing its mechanical properties, was determined with the help of a resistance moisture meter Tanel, model HIT5, with measurement precision of $0.1 \%$. During the moisture content measurements, the nominal density of pine wood as well as the temperature of the air-conditioned room, where the tests took place, were both taken into account. The density of each board was determined with the stereometric method.

The dynamic modulus of elasticity of individual boards (MOE_dyn) and their strength grade $\mathrm{C}$, were specified with the help of a Mobile Timber Grader (MTG) by the Brookhuis MicroElectronics Company (Brookhuis Applied Technologies, Enschede, The Netherlands). In case of boards with low modulus of elasticity and high amount of defects, the MTG rejected such piece of timber. In case of roughly cut board ends, the MTG device displayed the error message, informing that the strength grading (determination of modulus of elasticity and strength grade $\mathrm{C}$ ) for this piece of wood was not possible.

The global modulus of elasticity (MOE_EN-408) and modulus of rupture (MOR) were determined during a bending test with four points of support, using a universal testing machine - the TIRA Test 2300, in line with the EN 408 standard Timber structures - Structural timber and glued laminated timber - Determination of some physical and mechanical properties. The crosshead speed in the test amounted to $3 \mathrm{~mm} \cdot \mathrm{min}^{-1}$. The degree of bending of the boards was measured with an inductive sensor of the Novotechnik company, type TRS 75, 
with the precision of $0.01 \mathrm{~mm}$. During the test, the value of the bending strength and the degree of bending were recorded.

To determine the significance of differences between the average values, the t-Student (with a confidence level of 0.95) Statistica v.13.3 software was used.

\section{RESULTS AND DISCUSSION}

The results of moisture content and density tests for the structural timber sawn from butt, middle and top logs, have been presented in Tab. 1. If we assume an average density of boards sawn from butt logs at the level of $592 \mathrm{~kg} \cdot \mathrm{m}^{-3}$ to be $100 \%$, then the average density of boards from middle logs would amount to $92 \%$, and from top logs: $85 \%$ of the reference density. The differences in density between timber from different kinds of logs are statistically significant. The average density value for all timber pieces amounted to $547 \mathrm{~kg} \cdot \mathrm{m}^{-3}$, and moisture content to $11.6 \%$.

Tab. 1: Characteristics of the tested structural timber (boards). Moisture content (MC), density, strength class (from C18 to C40) graded with the help of an MTG device.

\begin{tabular}{|l|c|c|c|}
\hline \multirow{2}{*}{} & \multicolumn{3}{|c|}{ Boards cut from } \\
\cline { 2 - 4 } & butt logs & middle logs & top logs \\
\hline Number of boards & 70 & 70 & 70 \\
\hline Average MC $(\%)$ & 12.4 & 11.3 & 11.0 \\
\hline $\mathrm{SD}(\%)$ & 1 & 1 & 1 \\
\hline $\mathrm{COV}(\%)$ & 9 & 12 & 11 \\
\hline Average density $\left(\mathrm{kg} \cdot \mathrm{m}^{-3}\right)$ & 592 & 545 & 503 \\
\hline $\mathrm{SD}\left(\mathrm{kg} \cdot \mathrm{m}^{-3}\right)$ & 55 & 52 & 43 \\
\hline $\mathrm{COV}$ & 9 & 10 & 9 \\
\hline Number of boards C18 class & 2 & 4 & 9 \\
\hline Number of boards C24 class & 2 & 21 & 40 \\
\hline Number of boards C30 class & 18 & 23 & 17 \\
\hline Number of boards C35 class & 28 & 16 & 3 \\
\hline Number of boards C40 class & 16 & 5 & 0 \\
\hline Reject & 1 & 1 & 1 \\
\hline Error & 3 & 0 & 0 \\
\hline Average density in failure zone $\left(\mathrm{kg} \cdot \mathrm{m}^{-3}\right)$ & 583 & 527 & 483 \\
\hline SD $\left(\mathrm{kg} \cdot \mathrm{m}^{-3}\right)$ & 65 & 60 & 45 \\
\hline COV & 11 & 11 & 9 \\
\hline Width of annual rings (mm) & 1.7 & 1.8 & 1.9 \\
\hline
\end{tabular}

The density differences between boards sawn from different kinds of logs (butt, middle and top) translate into different shares of the highest quality grades (C40 and C35) in each of the three timber groups. The number of timber pieces classified in the grades $\mathrm{C} 40$ or $\mathrm{C} 35$ for butt, middle and top log timber groups, amounted to, respectively: 44, 21 and 3 pieces. In case of the lowest quality grade - C18 - the number of timber pieces in each of the groups (butt, middle and top logs) amounted to 2, 4 and 9, respectively. A lower density, and as a result, lower values of other mechanical properties of wood from the top logs, can be caused by a lower share 
of heartwood in this section of wood, and also by the presence of juvenile wood.

Three pieces from the butt log group could not be strength graded, because the non-destructive strength grading device displayed the ERROR message. Visual inspection of those pieces revealed strongly twisted fibres in two of them, exceeding the permitted value for the lowest strength grade according to the visual strength grading method. The third board had a low modulus of elasticity during bending.

As a consequence of the significant differences in density of boards sawn from butt, middle and top logs, the wood elasticity moduli determined with the non-destructive MOE_dyn and destructive MOE_EN-408 methods were very diverse. The differences were statistically significant. If we assume that the average value of MOE_dyn at the level of $15039 \mathrm{MPa}$ for butt logs corresponds to $100 \%$, then the MOE_dyn of boards from middle logs would amount to $86 \%$, and top logs, $76 \%$. In case of the global modulus of elasticity MOE_EN-408, butt logs had a modulus of elasticity of $13740 \mathrm{MPa}$, which would correspond to $100 \%$, while for middle and top logs it amounted to $85 \%$ and $75 \%$ of the reference modulus, respectively. All of the tested log groups (butt, middle and top) had higher values of MOE_dyn than MOE_EN-408 (Fig. 2).

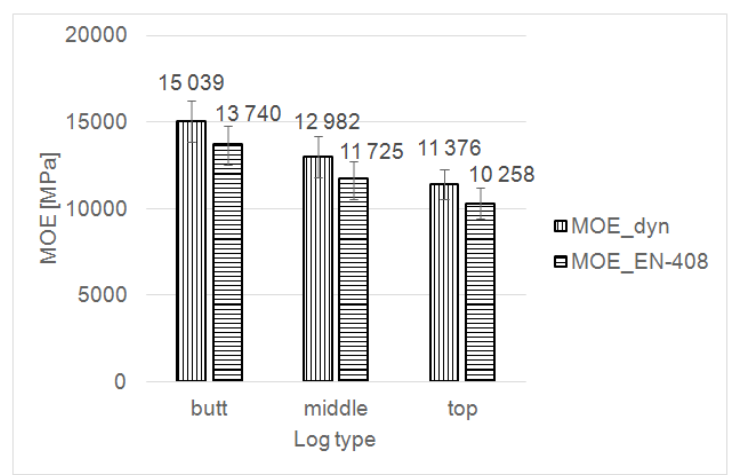

Fig. 2: Modulus of elasticity of boards made of butt, middle and top logs determined using the Mobile Timber Grader (MOE_dyn) and according to EN 408 (MOE_EN-408).

In case of all the three sets of timber under research, the ratio between MOE_dyn and MOE_EN-408 was similar, around 1.1. Therefore, the values of MOE_dyn were by about $10 \%$ higher than the values of MOE_EN-408 for the tested timber sets. The correlation between those two moduli (Fig. 3) is very high (coefficient of determination $\mathrm{R}^{2}$ between 0.84 and 0.89 ), and it has the highest value for butt $\log s-\mathrm{R}^{2}=0.89$. A similarly high correlation $\mathrm{R}=0.92$ $\left(\mathrm{R}^{2}=0.85\right)$ was quoted by Krzosek (2009) in his research.

Correlations between the dynamic and static moduli of elasticity for small control samples of pine wood without defects were also specified by Rautkari et al. (2014). They obtained coefficient of determination values at the level of 0.80 . The dynamic and static moduli of elasticity for pine sapwood, whose density amounted to ca. $490 \mathrm{~kg} \cdot \mathrm{m}^{-3}$, were $17.0 \mathrm{GPa}$ and 16.3 GPa, respectively. These results of modulus of elasticity were much higher due to the fact that the wood under research had no defects. Polish-grown pine timber for construction applications, originating from five different forestry regions, was tested by Krzosek et al. (2008) and Krzosek (2009). 


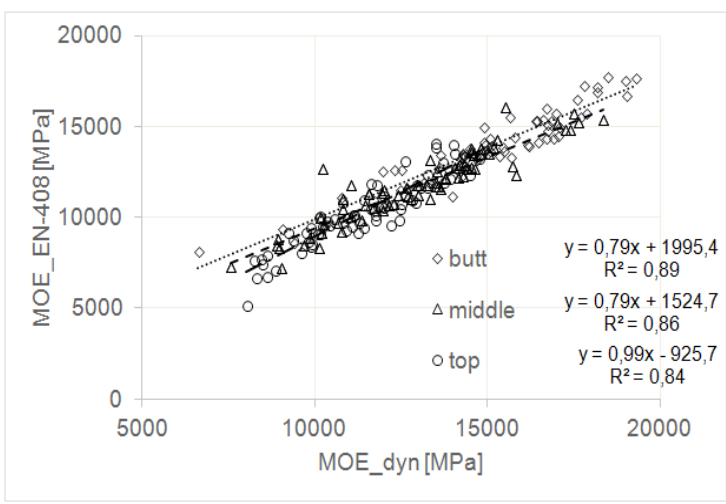

Fig. 3: Correlations between the modulus of elasticity of boards made of butt, middle and top logs determined using the Mobile Timber Grader (MOE_dyn) and according to EN 408 (MOE_EN-408).

His research revealed that wood from the regions of Pomerania and Kujawy-Pomerania had an average density of $525 \mathrm{~kg} \cdot \mathrm{m}^{-3}$ and $522 \mathrm{~kg} \cdot \mathrm{m}^{-3}$ - similarly to the density of wood from middle logs, while the values of global modulus of elasticity during bending, that is MOE_EN-408, amounted to $11183 \mathrm{MPa}$ and $11683 \mathrm{MPa}$, and were similar to the modulus of elasticity values for middle logs. Moreover, we can find data about Polish-grown pine timber in the work of Stapel et al. (2014). Timber with the density of $515 \mathrm{~kg} \cdot \mathrm{m}^{-3}$, has a bending strength at the level of 39.0 MPa and MOE_dyn: $12500 \mathrm{MPa}$. The wood density values determined with the stereometric method near the failure zone of a piece of timber during the destructive test were lower than for the entire board. This phenomenon results from the lack of knots in small samples. The growth ring width (annual growth) in butt, middle and top logs was quite similar and amounted to $1.7 \mathrm{~mm}, 1.8 \mathrm{~mm}$ and $1.9 \mathrm{~mm}$, respectively (Tab. 1). The performed tests revealed a high correlation between the values of global modulus of elasticity (MOE_EN-408) and density (R2 = 0.55) for all the timber pieces under research from the groups of butt, middle and top logs (Fig. 4).

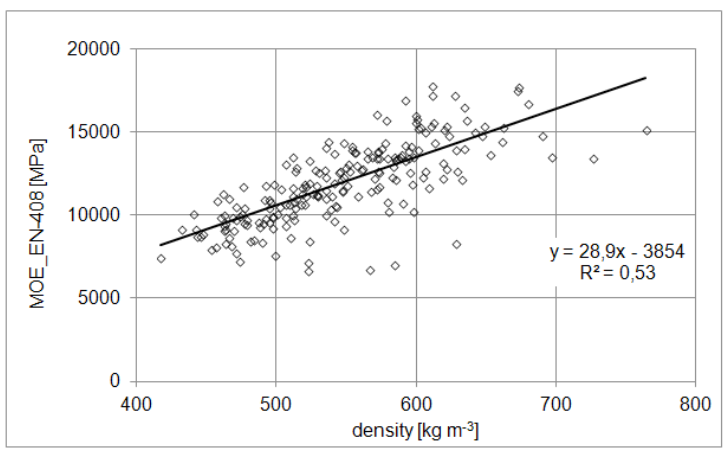

Fig. 4: Correlations between the global modulus of elasticity and density of all boards made of butt, middle and top logs determined according to EN 408 ( $\left.M O E_{-} E N-408\right)$.

The analysis of correlations of the global modulus of elasticity and density of individual groups of timber (from butt, middle and top logs) revealed weaker correlations (Fig. 5) 
$\left(\mathrm{R}^{2}=0.36 ; \mathrm{R}^{2}=0.42 ; \mathrm{R}^{2}=0.30\right.$, for timber cut from butt, middle and top logs, respectively). Higher correlations in similar kind of research (not taking into account the location of wood within the trunk) were obtained for pine wood $\mathrm{R}^{2}=0.72$ (Baltrušaitis and Mišeikytè 2011).

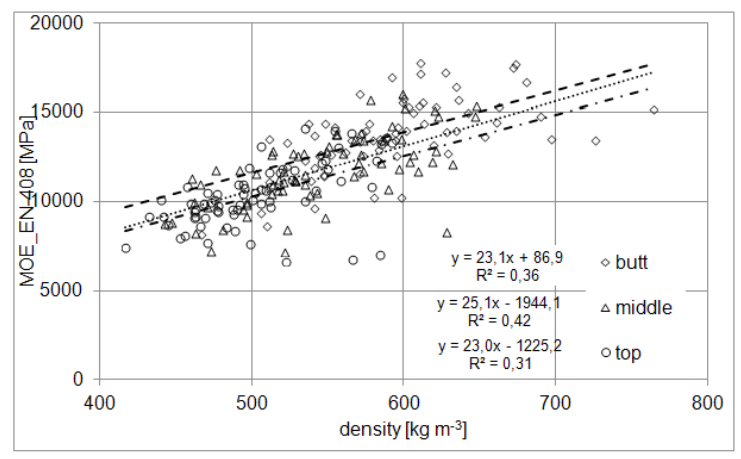

Fig. 5: Correlations between the global modulus of elasticity and density of separate board sets made of butt, middle and top logs, determined according to EN 408 (MOE_EN-408).

The analysis of results of the timber bending strength test (MOR) for timber sets made of butt, middle and top logs (Fig. 6) show that the highest average value was obtained for butt logs (61 MPa). If we assume that this value corresponds to $100 \%$, then the resistance of timber made of middle logs would amount to $69 \%$, and top logs only $61 \%$ of the strength measured for boards cut from butt logs. The differences between the average values calculated for each of the timber groups are statistically significant, according to the t Student programme. A comparison of these strength values with the differences observed for the global modulus of elasticity during bending, we can see that they are higher in case of the bending strength..

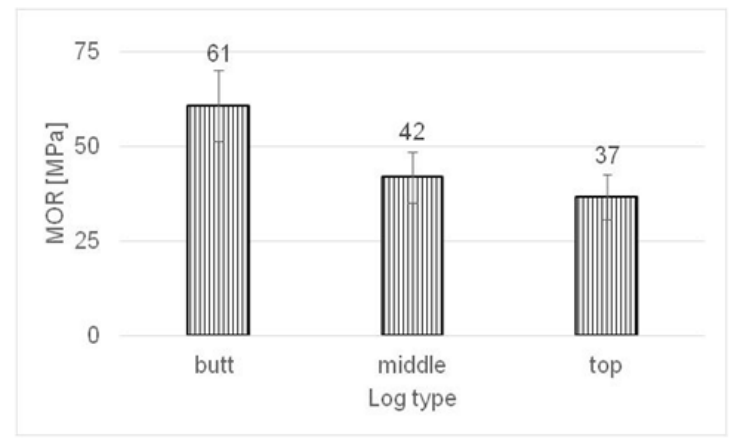

Fig. 6: Modulus of rupture (MOR) for boards made of butt, middle and top logs determined according to EN 408 .

Polish-grown pine timber for construction applications, originating from the forestry regions of Pomerania and Kujawy-Pomerania was studied by Krzosek et al. (2008); and the obtained results of average density were $525 \mathrm{~kg} \cdot \mathrm{m}^{-3}$ and $522 \mathrm{~kg} \cdot \mathrm{m}^{-3}$, similar to the density of middle logs; MOR values received by them amounted to $42 \mathrm{MPa}$ and $45 \mathrm{MPa}$, which also indicates 
mechanical properties similar to the value for middle logs. The results obtained for a larger set of pine timber obtained from five different Polish forestry regions (Krzosek 2009), were as follows: average timber density $510 \mathrm{~kg} \cdot \mathrm{m}^{-3}$ and average bending strength $36 \mathrm{MPa}$.

The results of tests described in the hereby paper indicate a lower correlation between the modulus of rupture (MOR) and wood density (Fig. 7) for all the structural timber pieces made of butt, middle and top logs (coefficient of determination, $\mathrm{R}^{2}=0.23$ ) than for the modulus of elasticity during bending (MOE_EN_408)

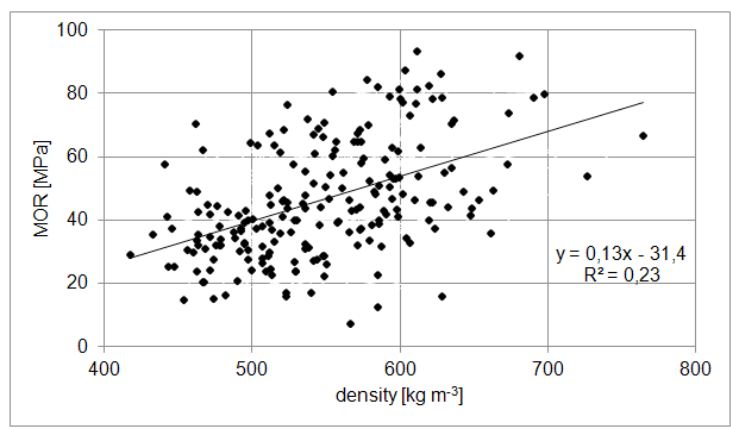

Fig. 7: Correlations between MOR and density for all tested boards made of butt, middle and top logs, determined according to EN 408.

For individual sets of structural timber made of butt, middle and top logs, MOR - density correlations are weaker and the coefficients of determination amount to $\mathrm{R}^{2}=0.15 ; \mathrm{R}^{2}=0.02$ and $\mathrm{R}^{2}=0.01$, respectively. The highest correlation between MOR and density was determined for butt logs (Fig. 8).

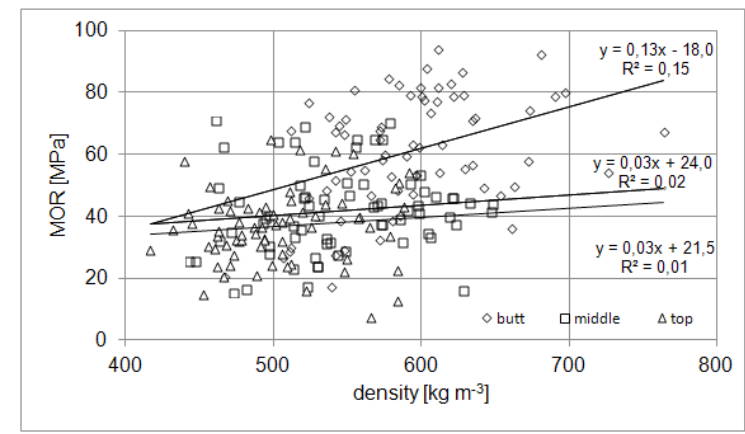

Fig. 8: Correlations between MOR and density of separate board sets made of butt, middle and top logs, determined according to EN 408. 


\section{CONCLUSIONS}

(1) The MOE_dyn, MOE_EN-408, and MOR for pine timber acquired from butt logs are higher than those for middle and top logs. We observed greater differences between the timber made of top and butt logs in case of MOR than MOE-dyn and MOE_EN-408. (2) MOE_dyn was by $10 \%$ higher than MOE_EN-408 for all the groups of timber: butt, middle and top. (3) The correlations between the global modulus of elasticity (MOE_EN-408) and wood density are stronger than the correlations between bending strength (MOR) and density. The above is true for all the sets of timber: butt, middle and top.

\section{ACKNOWLEDGMENTS}

The authors are grateful for the support of the National Centre for Research and Development, Poland, under "Environment, agriculture and forestry" - BIOSTRATEG strategic R\&D programme, agreement No BIOSTRATEG3/344303/14/NCBR/2018.

\section{REFERENCES}

1. Baltrušaitis, A., Mišeikyte, S., 2011: Strength and stiffness properties of the Lithuanian grown Scots pine (Pinus Sylvestris L.): Non-destructive testing methods vs. static. Wood Research 56(2): 157-168.

2. Bucur, V., 2003: Nondestructive characterization and imaging of wood. Springer Berlin, 214 pp.

3. DIN 4074-1, 2008: Strength grading of wood - part 1: Coniferous sawn timber.

4. DIN 4074-4, 2008. Strength grading of wood - Part 4: Certificate of suitability for devices supporting visual grading of sawn timber.

5. Denzler, J.K., Diebold, R., Glos, P., 2005: Machine strength gradingcommercially used grading machines-current developments. Proceedings of the 14th International Sympodium on Nondestructive Testing of Wood. University of Applied Science, Eberswalde, May 2-4, Pp 11- 16.

6. EN 338, 2004: Structural timber. Strength classes.

7. Glos, P., 1982: Die maschinelle Sortierung von Schnittholz. Stand der Technik - Vergleich der Verfahren. Holz-Zentralblatt 13: 153-155.

8. Glos, P., Diebold, R., Schleifer, A., 2000: Höherwertige Nutzung von Bauholz aus einheimischen Laub- und Nadelhölzern durch maschinelle Sortierverfahren. Institut Fûr Holzforschung, Múnchen, Abschlußbericht 98511, 195 pp.

9. Glos, P., Henrici, D., Lederem, B., 1999: Verbesserung der Wettbewerbsfähigkeit der Sägeindustrie durch Erhöhung der Schnittholzgualität. Bericht Nr. 96507. Institut für Holzforschung der Universität München. 85 pp.

10. Jelonek, T., Pazdrowski, W., Tomczak, A., 2009: Właściwości drewna sosny zwyczajnej (Pinus silvestris L.) na gruntach porolnych w północnej Polsce (Selected proprerties of wood in Scots pine (Pinus silvestris L.) growing on post-agricultural land in northern Poland). Leśne Prace Badawcze (Forest Research Papers) 70(3): 277-286.

11. Karlsson, M., 2009: Maschinelle Festigkeitssortierung mit dem Precigrader. Internationale Kongress der Säge und Holzindustrie. 16 - 17 Februar, Rosenheim, Pp 290-296. 
12. Krzosek, S., 1995: Maszynowe sortowanie tarcicy w Niemczech. (Strength grading of sawn timber in Germany) Przemysł Drzewny 2: 10-12.

13. Krzosek, S., 2009: Wytrzymałościowe sortowanie polskiej sosnowej tarcicy konstrukcyjnej różnymi metodami. (Strength grading of Polish structural pine timber with various methods). Wydawnictwo SGGW, Warszawa, 127 p.

14. Krzosek, S, Bacher, M., 2011: Aktueller Stand der maschinellen Festigkeitssortierung von Schnittholz in Polen und in Europa. Annals of Warsaw University of Life Science SGGW. Forestry and Wood Technology 74: 254-259.

15. Krzosek, S., Grześkiewicz, M., 2008: Strength grading Polish-grown Pinus Sylvestris L. structural timber using Timber Grader MTG and Visual method. Annals of Warsaw University of Life Science - SGGW. Forestry and Wood Technology 66: 26-31.

16. Krzosek, S., Grześkiewicz, M., Bacher, M., 2008: Mechanical properties of Polish-grown Pinus silvestris L. structural sawn timber. Conference COST E53, 29-30 October, Delft, The Netherlands, Pp. 253-260.

17. Mišeikyte, S., Baltrušaitis, A., Kudakas, L., 2008: Strength and stiffness properties of the Lithuanian grown Scots pine (Pinus sylvestris): Comparison of various testing methods. Proceedings of the 4th meeting of the Nordic Baltic network in wood material science and engineering (WSE), Latvian State Institute of Wood Chemistry, Pp 101-107 .

18. Noskowiak, A., 2017: Mechaniczne właściwości świerkowej tarcicy konstrukcyjnej pochodzącej z wybranych krain przyrodniczo-leśnych Polski. (Mechanical properties of spruce structural timber from selected Polish forestry regions. PhD thesis (in Polish). Warszawa, 110 pp.

19. Oberhofnerová, E., Arnetová, K., Holeček, T., Borůvka, V. Bomba, J., 2016: Determination of correlation between destructive and nondestructive methods applied on modified wood exposed to natural weathering test. BioResources 11(2): 5155-5168.

20. PN-D-94021, 2013: Structural sawn timber visual strength grade.

21. PN-EN 408: 2010 + A1, 2012: Timber structures. Structural timber and glued laminated timber. Determination of some physical and mechanical properties.

22. PN 93/D-02002, 1993: Surowiec drzewny - Podział, terminologia i symbole (Round wood. Classification, terminology and symbols).

23. Pošta, J., Ptáček, P., Jára, R., Terebesyová, M., Kuklík, P., Dolejš, J., 2016: Correlations and differences between methods for non-destructive evaluation of timber elements. Wood Research 61(1): 129-140.

24. Ranta-Maunus, A., 2009: Strength of European timber. Part 1. Analysis of growth areas based on existing test results. VTT Publications 706, 174 pp.

25. Ranta-Maunus, A., Denzler, J.K., Stapel, D., 2011: Strength of European timber. Part 2. Properties of spruce and pine tested in Gradewood project. VTT Working Papers $179,67 \mathrm{pp}$.

26. Rautkari, L., Honkanen, J., Hill, C.A.S., Ridley-Ellis, D., Hughes, M., 2014: Mechanical and physical properties of thermally modified Scots pine wood in high pressure reactor under saturated steam at 120,150 and 180. European Journal of Wood and Wood Product 72: 33-41.

27. Stapel, P., van de Kuilen, J.-W. G., 2014: Efficiency of visual strength grading of timber with respect to origin, species, cross section, and grading rules: A critical evaluation of the common standards. Holzforschung 68(2): 203-216.

28. Stod, R., Verkasalo, E., Heinonen, J., 2016: Quality and bending properties of sawn timber from commercial thinnings of Scots pine (Pinus sylvestris L.). Baltic Forestry 22 (1): 148-162. 
29. Teischinger, A., Patzelt, M., 2006: XXL-Wood. Materialkenngrößen als Grundlage für innovative Verarbeitungstechnologien und Produkte zur wirtschaftlichen nachhaltigen Nutzung der Österreichischen Nadelstarkholzreserven. Universität für Bodenkultur Wien. Berichte aus Energie- und Umweltforschung 27/2006, 137 pp.

30. Zeidler, A., Boruvka, V., Schönfelder, O., 2018: Comparison of wood quality of Douglas fir and spruce from afforested agricultural land and permanent forest land in the Czech Republic. Forests 9(1): 13.

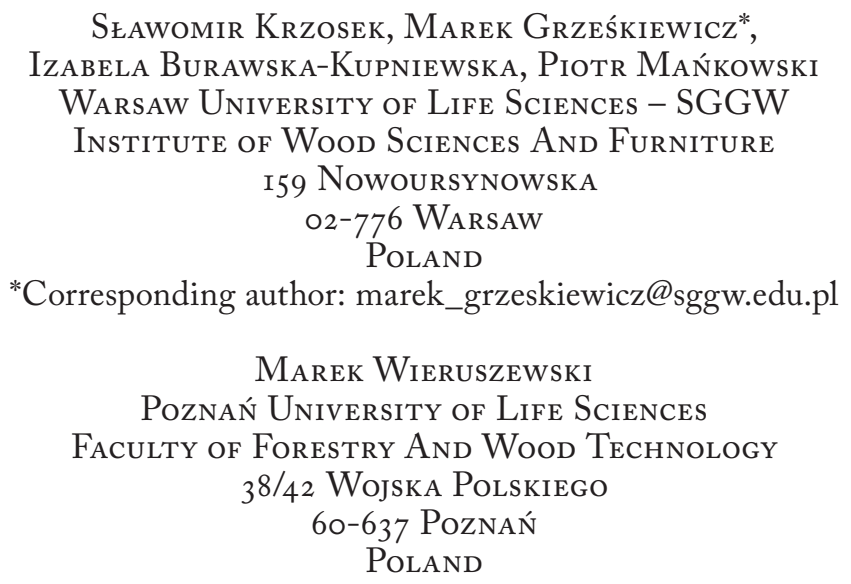

